\title{
PERBEDAAN PH SALIVA ANTARA BERKUMUR DAN TANPA BERKUMUR AIR PUTIH SETELAH MENGUNYAH MAKANAN BERKARBOHIDRAT SEDERHANA
}

\author{
Miftahul Jannah ${ }^{1}$, Hidayati ${ }^{2}$ dan Afriwardi ${ }^{3}$ \\ ${ }^{1}$ Mahasiswa Fakultas Kedokteran Gigi Universitas Andalas \\ ${ }^{2}$ Staf Pengajar Fakultas Kedokteran Gigi Universitas Andalas \\ ${ }^{3}$ Staf Pengajar Fakultas Kedokteran Universitas Andalas
}

\begin{abstract}
The Difference Of Salivary $\mathrm{pH}$ Between Rinsing and without Rinsing with Drinking Water After Chewing Simple Carbohydrate. Salivary $\mathrm{pH}$ is one of indicator in oral health. One factor that influences salivary $\mathrm{pH}$ is diet. Diet simple carbohydrates decrease salivary $\mathrm{pH}$. Rinsing with drinking water suspected that can increase salivary $p H$. to know how the difference of salivary $\mathrm{pH}$ between rinsing and without rinsing with drinking water after chewing simple carbohydrates. Quasi experimental used with pre test and post test design on 40 students as samples. The measurement of salivary $\mathrm{pH}$ was done by digital $\mathrm{pH}$ meter "Pen Type $\mathrm{pH}$ tester". The test which was used was paired T-test. The result Showed that Salivary $p H$ the rinsing group after chewing was $6.96 \pm 0.52$ and $7.02 \pm 0,50$ without rinsing. Salivary $p H$ after rinsing minutes to 5 was $6.94 \pm 0.52$ and $6.79 \pm 0.52$ without rinse. The pH of saliva rinsing the 20th minute was $7.12 \pm 0.49$ and $6.89 \pm 0.50$ without rinsing. The results of Paired t-test showed the significant difference from the salivary $\mathrm{pH}$ to 5 th minute after rinsing and without rinsing with chewing simple carbohydrate foods with $p<0.05(p=0.009)$ but, there was no significant difference of salivary $p H$ in the 20th minute and 5 minutes after rinsing and without rinsing with $p>0.05(p=$ 0.140 ). rinsing by using drinking water can increase the salivary $p H$ after chewing simple carbohydrate foods.
\end{abstract}

Keywords: Rinsing drinking water, Simple Carbohydrates, Salivary $p H$

Affiliasi Penulis : ${ }^{1}$ Faculty of Dentistry Andalas University. Jl. Perintis Kemerdekaan No 77, Padang, Sumatera Barat, Indonesia

Korespondensi: Miftahul Jannah

email: miftahuljannah770@yahoo.co.id

\section{PENDAHULUAN}

Masalah kesehatan gigi dan mulut di Indonesia merupakan masalah yang perlu mendapat perhatian, karena $90 \%$ penduduk Indonesia menderita penyakit gigi dan mulut, dan karies gigi merupakan masalah utamanya. Sesuai data global World Health Organization (WHO) (2000) menunjukkan 60-90\% anak-anak sekolah di negara industri memiliki karies atau lebih dikenal dengan gigi berlubang. Berdasarkan Riset Kesehatan Dasar (Riskesdas) (2013), prevalensi penduduk Indonesia yang memiliki masalah gigi dan mulut dalam 12 bulan terakhir sesuai Effective Medical Demand (EMD) adalah sebanyak 25,9 \%. Sedangkan peningkatan karies aktif pada penduduk Indonesia dibanding tahun 2007 lalu, yaitu dari 43,4\% (2007) menjadi $53,2 \%$ (2013). $^{1,2}$

Rata-rata indeks Decayed, Missing and Filling (DMF-T) Indonesia pada tahun 2013 adalah sebesar 4,6 yang berarti kerusakan gigi penduduk Indonesia 460 buah gigi per 100 orang. Provinsi yang memiliki indeks $D M F-T$ tertinggi adalah Bangka Belitung $(8,5)$ dan terendah adalah 
Papua Barat $(2,6)$ sedangkan daerah Sumatera Barat memiliki indeks $D M F-T$ sebesar 4,7. ${ }^{1,2}$ Banyak faktor yang mempengaruhi terjadinya karies. Faktor utama yang menyebabkan terjadinya karies gigi adalah host (gigi dan saliva), substrat (makanan), mikroorganisme, dan waktu. Karies gigi akan terbentuk apabila terjadi interaksi antara keempat faktor tersebut. ${ }^{3}$ Saliva sebagai faktor host berperan dalam mekanisme proteksi yang menjaga flora normal rongga mulut dan permukaan gigi yaitu pembersihan bakteri, aktivitas antibakteri, buffers, dan remineralisasi. Saliva mengandung beberapa zat anti bakteri antara lain IgA, amilase, lisozim, laktoperoksidase, histatin, dan laktoferin. Saliva juga memiliki sistem buffer yang berfungsi menetralkan kondisi asam yang timbul akibat pembentukan plak atau makanan dan minuman asam. ${ }^{4}$

Dalam keadaan normal gigi geligi selalu dibasahi oleh saliva. Kerentanan gigi terhadap karies banyak tergantung kepada lingkungannya, maka peran saliva sangat besar sekali. Cara perlindungan yang dilakukan saliva adalah dengan membentuk lapisan mukus sebagai pelindung mukosa, membantu menghambat pembentukan plak, mengatur $\mathrm{pH}$ rongga mulut, dan lain-lain. ${ }^{5,6}$

Saliva merupakan cairan kompleks yang diproduksi oleh kelenjar saliva dan mempunyai peranan penting dalam mempertahankan keseimbangan ekosistem di dalam rongga mulut. Komposisi kimia saliva menentukan $\mathrm{pH}$ dan kapasitas buffer saliva. $\mathrm{pH}$ saliva tergantung pada perbandingan asam dan basanya. Saliva mampu meremineralisasikan karies yang masih dini karena banyak sekali mengandung ion bikarbonat, kalsium dan fosfat. ${ }^{7}$

Saliva membantu pencernaan dan penelanan makanan, disamping itu juga mempertahankan integritas gigi, lidah, dan membran mukosa mulut. Di dalam mulut, saliva adalah unsur penting yang dapat melindungi gigi terhadap pengaruh luar, maupun dalam rongga mulut itu sendiri. Makanan yang kita makan dapat menyebabkan ludah kita bersifat asam maupun basa. ${ }^{8}$

Penelitian Vipeholm menyimpulkan bahwa konsumsi makanan dan minuman yang mengandung gula diantara jam makan dan pada saat makan berhubungan dengan peningkatan karies yang besar. Faktor makanan yang dihubungkan dengan terjadinya karies adalah jumlah fermentasi, konsentrasi dan bentuk fisik ( bentuk cair, padat, tepung) dari karbohidrat yang dikonsumsi, retensi di dalam mulut, frekuensi makan dan snacks serta lamanya waktu interval makan. $^{5}$ 
Bahan makanan pokok bagi sebagian masyarakat Indonesia banyak dimanfaatkan sebagai sumber karbohidrat bagi tubuh. Jenis karbohidrat lain seperti kentang, singkong, ubi jalar merupakan jenis makanan yang biasa dikonsumsi oleh anak-anak sekolah dengan frekuensi waktu 2-3 kali dalam sehari. ${ }^{8}$ Karbohidrat dalam makanan dapat dikelompokkan menjadi dua golongan, yaitu karbohidrat sederhana dan kompleks. Karbohidrat kompleks terdiri atas dua ikatan monosakarida yang disebut polisakarida. ${ }^{9}$ Pati merupakan simpanan karbohidrat utama yang dikonsumsi manusia seluruh dunia dan terdapat pada padi-padian, umbi-umbian, dan biji-bijian. Karbohidrat sederhana hanya terdiri dari satu atau dua ikatan molekul sakarida yaitu monosakarida dan disakarida, contohnya adalah sukrosa (gula tebu) dan laktosa (gula susu). Makanan yang termasuk golongan karbohidrat sederhana adalah es krim, manisan, permen, dan biskuit. ${ }^{10}$

Setelah makan khususnya makanan karbohidrat, akan terjadi fermentasi terhadap glukosa makanan. Hasilnya berupa senyawa bersifat asam dan membuat lingkungan sekitar gigi menjadi asam. Dalam beberapa menit derajat keasaman tadi akan meningkat atau $\mathrm{pH}$ nya turun. Bila berlanjut penurunan $\mathrm{pH}$ akan sampai ke nilai $\mathrm{pH}$ kritis. Nilai $\mathrm{pH}$ dalam keadaan normal adalah berkisar antara 5,67,6 dengan rata-rata $6,8 .^{11}$ Keberadaan perubahan suasana $\mathrm{pH}$ setelah makan ini akan kembali normal setelah 20-30 menit kemudian. Selama 5-10 menit pertama setelah makan adalah saat-saat kritis $\mathrm{pH}$ (sekitar 5,2-5,5). Makanan manis dan lengket mengandung karbohidrat yang merupakan sumber energi utama bagi bakteri mulut dan secara langsung terlibat dalam penurunan $\mathrm{pH}$. Jenis karbohidrat yang paling cocok bagi produksi asam oleh bakteri adalah karbohidrat sederhana atau yang lebih dikenal dengan gula-gula sederhana seperti sukrosa, fruktosa, glukosa, maltosa yang terdapat di dalam makanan manis dan lengket seperti coklat, permen, dan biskuit. Gula-gula ini mempunyai molekul yang kecil sehingga mudah berdifusi ke dalam plak dan dengan cepat akan dipecah oleh bakteri. ${ }^{10,13}$ Glukosa merupakan bagian utama diet penduduk di Indonesia. Selain sebagai makanan pokok, gula juga dikonsumsi sebagai makanan ringan atau camilan seperti yang terdapat dalam permen, wafer, biskuit, kue dan minuman ringan. Menurut penelitian di posyandu di wilayah DKI Jakarta tahun 1993, diperoleh data bahwa sekitar 96,7\% ibu membelikan jajan makanan manis kepada anaknya dan hanya $33,3 \%$ yang membelikan jajan yang mengandung protein. Jenis gula yang 
paling banyak digunakan adalah sukrosa. Konsumsi sukrosa dalam jumlah besar dapat menurunkan kapasitas buffer saliva sehingga mampu meningkatkan insiden terjadinya karies. ${ }^{14}$

Biskuit merupakan jenis makanan dengan memiliki kadar karbohidrat atau gula sederhana yang banyak di konsumsi oleh masyarakat terutama anak-anak karena sangat praktis untuk camilan diantara waktu makan, ditambah lagi memiliki variasi yang lebih beragam serta mudah didapat. Biskuit dikonsumsi oleh seluruh kalangan usia, baik bayi hingga dewasa namun dengan jenis yang berbedabeda. Biskuit merupakan makanan praktis karena dapat dimakan kapan saja, biskuit juga memiliki daya simpan yang relatif lama. ${ }^{10}$

Anak-anak usia sekolah menyukai makanan yang manis-manis seperti biskuit, permen, coklat dan makanan manis lainnya karena selain dari rasanya yang manis tetapi juga memiliki kemasan yang menarik dan bervariasi. ${ }^{8}$ Berdasarkan hasil penelitian Worotitjan et al (2013) frekuensi anak-anak yang mengkonsumsi makanan kariogenik seperti kue, roti adalah yang paling banyak dikonsumsi per hari yaitu 23 kali. Gaya hidup modern yang ingin serba cepat, sehingga merubah gaya hidup masyarakat untuk konsumsi makanan cepat saji yang kurang sehat yang akhirnya akan berpengaruh terhadap pola konsumsi makanan. $^{14}$

Berbagai cara dilakukan untuk menjaga kesehatan mulut. Pengendalian kesehatan mulut dapat dilakukan dengan cara mekanis seperti menyikat gigi dan secara kimiawi dengan berkumur. Berkumur dapat membersihkan rongga mulut dari debris, mencegah dan mengurangi akumulasi plak dan berpengaruh secara langsung terhadap saliva. Berdasarkan hasil penelitian Amalia (2014) adanya peningkatan $\mathrm{pH}$ saliva setelah berkumur dengan menggunakan larutan teh putih. Penelitian lain juga menyebutkan bahwa adanya peningkatan $\mathrm{pH}$ saliva setelah berkumur dengan larutan siwak. $^{13,15}$

Salah satu hal sederhana, murah, efisien dan tanpa efek samping yang dapat dilakukan dalam menjaga kesehatan mulut adalah dengan berkumur dengan air putih. Berkumur dengan air putih dapat membuang sisa-sisa makanan dalam rongga mulut, fluor yang terkandung didalamnya dapat menghambat proses demineralisasi, dan berikatan dengan komponen enamel gigi, mengurangi aktifitas mikroorganisme, dan dapat berpengaruh secara langsung terhadap saliva. $^{12,14}$

Tujuan peneletian ini adalah untuk mengetahui perbedaan $\mathrm{pH}$ saliva antara 
berkumur dan tanpa berkumur dengan air putih setelah mengunyah makanan berkarbohidrat sederhana.

\section{METODE PENELITIAN}

Desain penelitian ini adalah penelitian eksperimental. Rancangan penelitian adalah pre-test and post-test design dengan menggunakan rumus penelitian analitik numerik berpasangan dua kelompok. ${ }^{16}$ Sampel dipilih sesuai kriteria inklusi yang berjumlah 40 orang yang terbagi menjadi kelompok A pada hari pertama penelitian (pre test) dan B pada hari kedua (post test). Penelitian ini dilakukan di SDN 02 Jambak pada Bulan Februari-Maret 2016.

Penelitian ini dilakukan setelah mendapatkan ethical clearance. Sampel diberikan informasi sebelum dilakukan kegiatan penelitian. Kegiatan penelitian terdiri dari penandatangan informed consent, pada hari pertama kegiatan penelitian sampel diinstruksikan untuk menyikat gigi dan tidak mengkonsumsi makanan dan minuman 1 jam sebelum penelitian, sampel diminta untuk duduk rileks, kemudian sampel diinstruksikan untuk mengumpulkan salivanya menggunakan metode spitting, dimana saliva dikumpulkan di dalam mulut, jika mulut sudah mulai terasa penuh kemudian sampel penelitian diinstruksikan untuk meludahkannya ke dalam wadah saliva (gambar 1). Saliva yang dikumpulkan adalah saliva sebelum stimulasi. Kemudian Sampel diinstruksikan untuk mengunyah 75 gram biskuit selama 1 menit lalu ditelan dan dimakan sampai habis. Pada menit ke 5 setelah makan, responden diminta untuk mengumpulkan salivanya kembali di dasar mulut, jika mulut sudah mulai terasa penuh lalu dikeluarkan dengan metode spitting ke wadah yang telah disediakan. di instruksikan untuk berkumur dengan $40 \mathrm{ml}$ air putih secara kuat ke seluruh permukaan mulut lalu dikeluarkan, lakukan sebanyak 3 kali. Pada menit ke 5 dan 20 Setelah berkumur, sampel diinstruksikan untuk mengumpulkan salivanya menggunakan metode spitting, dimana saliva dikumpulkan di dalam mulut, kemudian sampel penelitian diinstruksikan untuk meludahkannya ke dalam wadah saliva. $\mathrm{pH}$ saliva diukur dengan cara mencelupkan $\mathrm{pH}$ meter (gambar 2) ke dalam wadah saliva. Amati perubahan angka pada monitor $\mathrm{pH}$ meter dan dicatat hasil perubahannya.

Kegiatan penelitian pada hari kedua adalah sampel diinstruksikan untuk menyikat gigi dan tidak mengkonsumsi makanan dan minuman 1 jam sebelum penelitian, sampel diminta untuk duduk rileks. Sampel diinstruksikan untuk mengumpulkan salivanya menggunakan metode spitting, dimana saliva dikumpulkan di dalam mulut kemudian 
sampel penelitian diinstruksikan untuk meludahkannya ke dalam wadah saliva. Operator mencelupkan $\mathrm{pH}$ meter ke dalam wadah saliva. Amati perubahan angka pada monitor $\mathrm{pH}$ meter dan dicatat hasil perubahannya. $\mathrm{pH}$ yang didapat adalah $\mathrm{pH}$ sebelum stimulasi.

Sampel diinstruksikan untuk mengunyah 75 gram biskuit selama 1 menit lalu ditelan dan dimakan sampai habis. Tanpa berkumur, pada menit ke 5 setelah makan, sampel diminta untuk mengumpulkan salivanya kembali di dasar mulut, jika mulut sudah mulai terasa penuh lalu dikeluarkan dengan metode spitting ke wadah yang telah disediakan. di instruksikan untuk tidak berkumur dengan air putih. Pada menit ke 10 dan 20 setelahnya, sampel diinstruksikan untuk mengumpulkan salivanya menggunakan metode spitting, dimana saliva dikumpulkan di dalam mulut, kemudian responden penelitian diinstruksikan untuk meludahkannya ke dalam wadah saliva. $\mathrm{pH}$ saliva diukur dengan cara mencelupkan $\mathrm{pH}$ meter ke dalam wadah saliva.

\section{(A)}

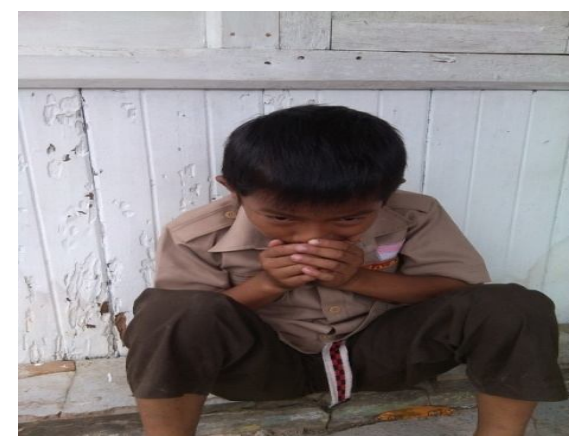

(B)

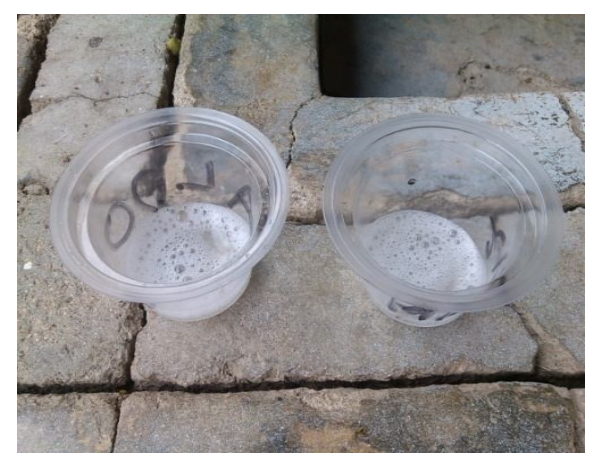

Gambar 1 (A dan B) Pengumpulan saliva pada wadah

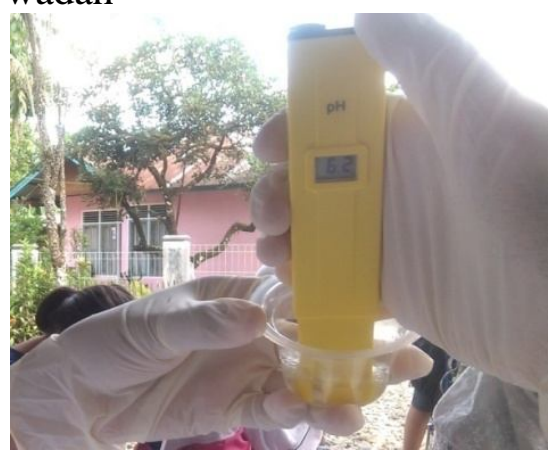

Gambar 2. Pengukuran $\mathrm{pH}$ saliva

\section{HASIL PENELITIAN}

Analisa univariat mendeskripsikan distribusi $\mathrm{pH}$ saliva sebelum dan setelah perlakuan, untuk melihat rata-rata dan standar deviasi, nilai minimum, dan maksimum masing-masing perlakuan seperti yang terlihat pada tabel 1 .

Tabel 1. pH Saliva Mengunyah Makanan Berkarbohidrat Sederhana yang Diikuti Berkumur (Kelompok A) dan tanpa diikuti Berkumur (Kelompok B)

\begin{tabular}{|c|c|c|c|c|c|c|c|}
\hline \multirow[t]{2}{*}{ Wakts } & \multicolumn{3}{|c|}{$\begin{array}{c}\text { Kelompok A } \\
\text { (Berikumvr) }\end{array}$} & \multicolumn{3}{|c|}{$\begin{array}{c}\text { Kelompok B } \\
\text { (tanpa berkumur) }\end{array}$} & \multirow[t]{2}{*}{$\mathrm{N}$} \\
\hline & Mean $=$ sd & $\overline{\mathrm{Min}}$ & Maks & Mean $=$ sd & Min & Maks & \\
\hline $\begin{array}{l}\text { Sebelum } \\
\text { mengunyah }\end{array}$ & $7,12 \pm 0,51$ & 5,80 & 8,20 & $7,20=0,53$ & 6,10 & 8,20 & 40 \\
\hline $\begin{array}{l}\text { Setelah } \\
\text { mengunyah }\end{array}$ & $6,96 \pm 0,52$ & 5,70 & 7,80 & $7,02 \pm 0,50$ & 5,60 & 8,00 & 40 \\
\hline Menit ke 5 & $6,94 \pm 0,52$ & 5,20 & 7,70 & $6,79=0,52$ & 5,50 & 7,70 & 40 \\
\hline Menit ke 20 & $7,12 \pm 0,49$ & 5,90 & 8,30 & $6,89=0,50$ & 5,70 & 7,70 & 40 \\
\hline
\end{tabular}


Analisa bivariat dilakukan untuk melihat hubungan dua variabel yaitu jenis perlakuan mengunyah makanan berkarbohidrat sederhana dengan $\mathrm{pH}$ saliva, dan berkumur dengan $\mathrm{pH}$ saliva menggunakan uji $\mathrm{t}$ (t-test). Nilai uji Shapiro Wilk dipakai untuk melihat normalitas data, apabila hasil uji signifikan ( $p>0,05)$ berarti data berdistribusi normal. Berdasarkan uji normalitas didapatkan nilai $\mathrm{pH}$ saliva setelah berkumur menit ke $10, \mathrm{p}=0,013 \mathrm{pH}$ saliva yang artinya data berdistribusi tidak normal. Lakukan transformasi data untuk data yang tidak terdistribusi normal. Jika hasil transformasi data terdistribusi normal, maka dipakai uji Paired T-test. Jika hasil tansformasi data tidak terdistribusi normal, analisa dilakukan dengan uji non parametrik pada uji yang melibatkan data $\mathrm{pH}$ saliva setelah berkumur menit ke 10 dan selisih $\mathrm{pH}$ saliva setelah berkumur menit ke 10 dengan menit ke-5 setelah mengunyah makanan. Uji normalitas Shapiro-Wilk dilakukan untuk melihat data terdistribusi normal atau tidak (tabel 2)

Tabel 2. Uji Normalitas Saphiro Wilk

\begin{tabular}{lccccccc}
\hline \multicolumn{1}{c}{ Waktu } & \multicolumn{3}{c}{$\begin{array}{c}\text { Kelompok A } \\
\text { (Berkumur) }\end{array}$} & \multicolumn{4}{c}{$\begin{array}{c}\text { Kelompok B } \\
\text { (tanpa berkumur) }\end{array}$} \\
\hline & Statistic & $d f$ & $p$ & Statistic & $D f$ & $P$ \\
\hline $\begin{array}{l}\text { Sebelum } \\
\text { mengunyah }\end{array}$ & 0,975 & 40 & 0,499 & 0,980 & 40 & 0,694 \\
\hline $\begin{array}{l}\text { Setelah mengunyah } \\
\text { Menit ke 5 }\end{array}$ & 0,952 & 40 & 0,087 & 0,966 & 40 & 0,271 \\
\hline Menit ke 20 & 0,927 & 40 & $0,013^{*}$ & 0,971 & 40 & 0,383 \\
\hline
\end{tabular}

\section{Data terdistribusi tidak normal $(\mathbf{p}<0,05)$}

Berdasarkan uji normalitas ShapiroWilk (tabel 2), didapatkan bahwa data terdistribusi normal dengan $\mathrm{p}>0,05$, data yang tidak terdistribusi normal $(\mathrm{p}<0,05)$ dilakukan transformasi data, Berdasarkan hasil uji normalitas tersebut, maka uji $\mathrm{T}$ dependen dapat dilakukan.

Distribusi $\mathrm{pH}$ saliva kelompok A (berkumur) dan B (tanpa berkumur) dapat dilihat pada grafik 1

Grafik 1. Gambaran pH saliva diantara kedua kelompok (A dan B)

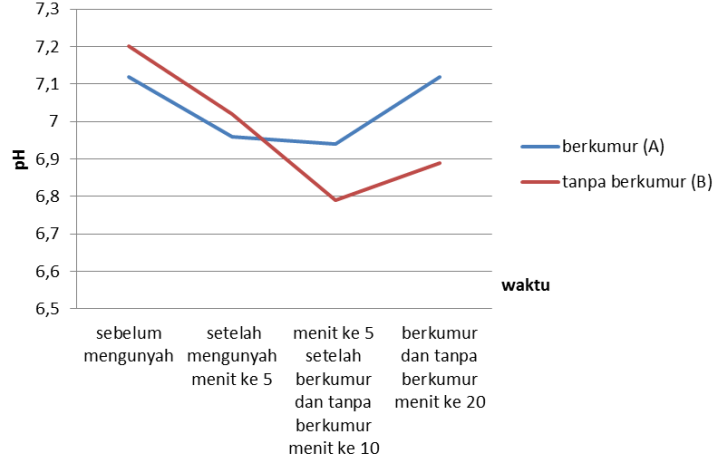

sedangkan perbedaan selisih rata-rata antara kedua kelompok tersebut dapat dilihat pada tabel 3 .

Tabel 3. Selisih Rata-rata $\mathrm{pH}$ Saliva Antara Kedua Kelompok

\begin{tabular}{lccc}
\hline & \multicolumn{3}{c}{ Selisih pH salira } \\
\cline { 2 - 4 } Kelompok & $\begin{array}{c}\text { Setelah } \\
\text { mengunyah } \\
\text { dengan } \\
\text { sebelum }\end{array}$ & $\begin{array}{c}\text { Menit ke 5 } \\
\text { dengan setelah } \\
\text { mengunyah }\end{array}$ & $\begin{array}{c}\text { Menit ke 20 } \\
\text { dengan menit } \\
\text { ke5 }\end{array}$ \\
\hline $\begin{array}{l}\text { KelompokA } \\
\text { (Berkumur) }\end{array}$ & $0,19 \pm 0,37$ & $0,02 \pm 0,33$ & $0,19 \pm 0,33$ \\
$\begin{array}{l}\text { Kelompok(B) } \\
\text { (tanpa berkumur) }\end{array}$ & $0,20 \pm 0,46$ & $0,23 \pm 0,37$ & $0,10 \pm 0,29$ \\
\hline$p$ & 0,754 & 0,009 & 0,140 \\
\hline
\end{tabular}

Signifikan jika $\mathrm{p}<0,05$

PEMBAHASAN 
Penelitian ini dilakukan untuk mengetahui perbedaan $\mathrm{pH}$ saliva antara berkumur (A) dan tanpa berkumur air putih (B) setelah mengunyah makanan berkarbohidrat sederhana. Dari hasil penelitian yang dilakukan pada 40 orang sampel pada siswa/i SD N 02 Jambak yang melakukan instruksi mengunyah makanan berkarbohidrat sederhana diikuti dengan berkumur air putih dan tanpa berkumur, didapatkan nilai rata-rata $\mathrm{pH}$ saliva sebelum stimulasi (kelompok A) adalah $7,12 \pm 0,51$ dan nilai rata-rata $\mathrm{pH}$ saliva sebelum (kelompok B) adalah 7,20 \pm 0,53, terdapat sedikit perbedaan namun hal ini masih berada dalam rentang $\mathrm{pH}$ saliva normal, bahwa normalnya nilai rata-rata $\mathrm{pH}$ saliva manusia berkisar antara 5,6$7,6{ }^{26}$ Sampel tidak makan, minum, dan menyikat gigi sebelum diberi perlakuan.

Nilai rata-rata $\mathrm{pH}$ saliva setelah mengunyah makanan berkarbohidrat sederhana kelompok A adalah 6,96 \pm 0,52 dan kelompok B adalah 7,02 $\pm 0,52$, yang didapatkan pada perlakuan setelah mengunyah makanan berkarbohidrat sederhana pada menit ke-5. Terlihat bahwa $\mathrm{pH}$ saliva setelah mengunyah makanan berkarbohidrat sederhana pada menit ke-5 mengalami penurunan dari sebelum stimulasi. Hal ini sejalan dengan penelitian Ramayanti (2013) yang menyatakan bahwa setelah diet makanan yang mengandung karbohidrat akan terjadi fermentasi yang hasilnya berupa senyawa bersifat asam dan membuat lingkungan sekitar gigi menjadi asam sehingga $\mathrm{pH}$ saliva mengalami penurunan. ${ }^{10}$ Penelitian Houwink (1993) juga menyatakan bahwa dalam beberapa menit $\mathrm{pH}$ saliva akan mengalami penurunan setelah memakan makanan yang mengandung karbohidrat. ${ }^{20}$ Memakan makanan yang mengandung karbohidrat akan lebih cepat difermentasikan oleh bakteri karena mengandung gula sederhana yang memiliki molekul yang kecil sehingga mudah berdifusi ke dalam plak. $^{9,11}$

Setelah makan khususnya makanan karbohidrat, akan terjadi fermentasi terhadap glukosa makanan. Hasilnya berupa senyawa bersifat asam dan membuat lingkungan sekitar gigi menjadi asam. Dalam beberapa menit derajat keasaman tadi akan meningkat atau $\mathrm{pH}$ nya turun. Bila berlanjut penurunan $\mathrm{pH}$ akan sampai ke nilai $\mathrm{pH}$ kritis. Nilai $\mathrm{pH}$ dalam keadaan normal adalah berkisar antara 5,67,6 dengan rata-rata $6,8 .^{11}$

Diet karbohidrat dapat mempengaruhi $\mathrm{pH}$ dan kapasitas buffer saliva. Diet kaya karbohidrat dapat menurunkan kapasitas buffer saliva, sedangkan diet kaya protein dapat mempunyai efek meningkatkan buffer saliva. Diet karbohidrat meningkatkan 
metabolisme produksi asam oleh bakteri rongga mulut. ${ }^{17,18}$

Hasil paired t-test menunjukkan selisih rata-rata $\mathrm{pH}$ saliva pada menit ke 5 setelah mengunyah makanan dengan sebelum mengunyah kelompok A adalah 0,19 $\pm 0,37$, sedangkan kelompok B sebesar $0,20 \pm 0,46$. Namun tidak terdapat perbedaan bermakna secara statistik $\mathrm{pH}$ saliva antara kedua kelompok $(\mathrm{p}>0,05)$. Hal ini dikarenakan responden adalah orang yang sama sehingga tidak ada perbedaan.

Selisih rata-rata $\mathrm{pH}$ saliva setelah berkumur menit ke 5 dengan setelah mengunyah makanan kelompok $\mathrm{A}$ adalah $0,02 \pm 0,33$ sedangkan pada kelompok B adalah sebesar $0,23 \pm 0,38$. Terdapat perbedaan bermakna secara statisitik dari selisih rata-rata $\mathrm{pH}$ saliva kedua kelompok, hal ini ditunjukkan dengan nilai $\mathrm{p}<0,05$ $(\mathrm{p}=0,009)$. Dari hasil penelitian didapatkan rata-rata $\mathrm{pH}$ saliva setelah berkumur mengalami peningkatan dari $\mathrm{pH}$ saliva setelah mengunyah makanan berkarbohidrat sederhana, hal ini membuktikan bahwa dengan berkumur secara kuat ke seluruh permukaan mulut dapat membuang sisa-sisa debris makanan dalam rongga mulut sehingga mengurangi aktifitas bakteri dan memberikan efek mekanis yang dapat berpengaruh pada saliva. $^{13}$
Selisih rata-rata $\mathrm{pH}$ saliva setelah berkumur menit ke 20 (kelompok A) adalah $0,19 \pm \quad 0,33$ sedangkan pada kelompok tanpa berkumur menit ke 20 (kelompok B) adalah sebesar 0,10 \pm 0,29. Namun tidak terdapat perbedaan yang bermakna dari kedua kelompok tersebut. Hal ini menandakan bahwa pada menit ke 20 tersebut sistem buffer saliva sudah bekerja dengan baik. Untuk kembali normal, $\mathrm{pH}$ saliva membutuhkan waktu sekitar 20-60 menit setelah stimulasi. ${ }^{10,11,48}$ Sistem buffer saliva berfungsi menetralkan kondisi asam yang timbul akibat pembentukan plak atau makanan dan minuman asam. ${ }^{4}$

Peningkatan $\mathrm{pH}$ saliva dipengaruhi adanya peningkatan aktfitas buffer oleh bikarbonat. Konsentrasi bikarbonat berbanding lurus dengan kecepatan sekresi saliva. Peningkatan konsentrasi bikarbonat dapat menyebabkan peningkatan kapasitas buffer sehingga terjadi peningkatan $\mathrm{pH}$ saliva. $^{48}$ Meskipun tidak terdapat perbedaan yang begitu siginifikan pada menit ke 20 antara kedua kelompok namun berkumur menggunakan air putih dapat memberi pengaruh terhadap $\mathrm{pH}$ saliva. saran yang disampaikan pada penelitian ini adalah agar setelah mengkonsumsi makanan yang mengandung karbohidrat sederhana segeralah berkumur dengan air putih secara kuat ke seluruh permukaan 
mulut untuk membantu menetralisir asam yang ditimbulkan.

\section{KESIMPULAN}

Berdasarkan penelitian ini dapat disimpulkan bahwa rata-rata $\mathrm{pH}$ saliva sebelum mengunyah makanan berkarbohidrat sederhana kelompok A (berkumur) dan B (tanpa berkumur) pada penelitian ini masih berada pada rentang pH saliva normal. $\mathrm{pH}$ saliva pada kelompok A (berkumur) dan B (tanpa berkumur ) mengalami penurunan pada menit ke lima setelah mengunyah makanan berkarbohidrat sederhana. Terdapat perbedaan yang signifikan selisih $\mathrm{pH}$ saliva pada menit ke 5 setelah berkumur (kelompok A) dibanding dengan kelompok tanpa berkumur (kelompok B) dan tidak terdapat perbedaan yang signifikan selisih pH saliva pada menit ke 20 setelah berkumur (kelompok A) dengan kelompok tanpa berkumur (kelompok B).

\section{KEPUSTAKAAN}

1. Departemen Kesehatan Republik Indonesia. Laporan Riset Kesehatan Dasar. 2013.

2. Departemen Kesehatan Republik Indonesia. Laporan Riset Kesehatan Dasar. 2007.

3. Budijanto, D. "93 Juta Lebih Penduduk Indonesia Menderita Karies Aktif'. http://www.kompasiana.com/de-be/93-jutalebih-penduduk-indonesia-menderita-kariesaktif 54f5d589a33311b5538b474f. diakses 17 oktober 2015. Artikel Ilmiah Pusat Data dan Informasi, 2015.
4. Sulendra, K.T., Fatmawati., Nugroho A. Relationship between salivary $\mathrm{pH}$ and Viscosity to DMF-T index of pupils in Balet Baru I and Balet Baru II Elementary School. Artikel Ilmiah Fakultas Kedokteran Gigi Universitas Jember, 2013.

5. Kidd, A.M Edwina, dan Bechal. Dasar-Dasar Karies: Penyakit dan Penanggulangannya. Jakarta: EGC, 1991.

6. Rho MB, Deschler DG. Anatomy Salivary Gland. In : Witt RL. Salivary Gland Desease Surgical and Medical Management. New York : Thieme Medicel Publishers, 2005.

7. Apriyono, DK dan Nadie, F. Pengaruh Kumur-kumur dengan Larutan Triclosan 3\% terhadap $\mathrm{pH}$ Saliva”. Cermin Dunia Kedokteran. Jurnal Kedokteran Gigi Universitas Jember, 2011;38(6): 425-427.

8. Worotitjan, I et al. Pengalaman Karies Gigi Serta Pola Makan Dan Minum Pada Anak Sekolah Dasar Di Desa Kiawa Kecamatan Kawangkoan Utara. Jurnal e-GiGi, 2013; 1(1): 59-68.

9. Nantel, G. Carbohydrates in Human Nutrition. Nutrition Planning Group, Assesment and Evaluation Service. Food and Nutrition Division: FAO, 1999.

10. Ramayanti, Sri dan Idral Purnakarya. Peran Makanan Terhadap Kejadian Karies Gigi. Jurnal Kesehatan Masyarakat, 2013; 7(2): 8993.

11. Amerongen, AN, et al. Ludah dan kelenjar Ludah Arti Bagi Kesehatan Gigi. Yogyakarta : Gajah Mada University Press, 1992.

12. Moynihan,P, Poul Erik. Diet, Nutrition and The Prevention of Dental Diseases. WHO Collaborating Centre for Nutrition and Oral Health, School of Dental Science. Denmark: University of Copenhagen, 2004; 7(1A): 201226. 
13. Lipoeto I, Adzakiyah T, Kusuma N. Effect of Gargling by Using Siwak Extract (Salvadora persica) to The Saliva $\mathrm{pH}$ of Oral Cavity. Journal of Pharmacy and Clinics, 2015; 2(1): 74-77.

14. Najoan, BS et al. Perubahan Ph Saliva Siswa Ma Darul Istiqamah Manado Sesudah Menyikat Gigi dengan Pasta Gigi Mengandung Xylitol. Jurnal e-GiGi, 2014; 2(2).

15. Amalia, N, Kaidah S, Widodo. Perbandingan Efektifitas Berkumur Larutan Teh Putih (Camellia sinensis) Seduh Konsentrasi 100\% dengan 50\% dalam Meningkatkan pH Saliva, 2014; 2(1).

16. Dahlan, M.Sopyudin. Besar Sampel dan Cara Pengambilan Sampel dalam Penelitian Kedokteran Dan Kesehatan. Jakarta: Salemba Medika, 2013.

17. Almeida, PD, Gregio, AMT, Machado, Lima de Suares, Azevedo. Saliva Composition and Function: A Comprehensive Review.The Journal Of Contemporary Dental Practice, 2008; 9(3).

18. Parvasani, A. 2012. Pengaruh Radioterapi Pada Kepala dan Leher Terhadap Ph Saliv. (Laporan Karya Tulis Ilmiah). http://core.ac.uk/download/pdf/11735721.pdf. Diakses 25 November 2015. 